\title{
Insider Trading and the Classification of Seasoned Equity Offerings: Evidence from Taiwan
}

\author{
Han-Ching Huang ${ }^{1} \&$ Hsiu-Hsin Chiu $^{2}$ \\ ${ }^{1}$ Department of Finance, Chung Yuan Christian University, Chung Li, Taiwan \\ ${ }^{2}$ International Master of Business and Administration, Chung Yuan Christian University, Chung Li, Taiwan \\ Correspondence: Han-Ching Huang, Department of Finance, Chung Yuan Christian University, Chung Li, \\ Taiwan. Tel: 886-3265-5710. E-mail: samprass@ @ cycu.edu.tw
}

Received: March 2, 2017

Accepted: March 31, 2017

Online Published: April 15, 2017

doi:10.5539/ijef.v9n5p58

URL: https://doi.org/10.5539/ijef.v9n5p58

\begin{abstract}
This paper investigates whether insider purchasing or selling before Season equity offerings (SEO) announcement have the impact on the cumulative abnormal returns (CAR) around SEO announcement in Taiwan. We find that there are negative announcement effects around the SEO announcement, which is not consistent with the argument that there are usually positive announcement effects around the SEO announcement in Taiwan. Moreover, long-run abnormal returns following SEOs are negative. Therefore, the motivation of SEO has changed from investment to overvaluation.. Although there is net buying prior to SEO announcement, the outside investors still regard SEO announcement as a signal of overvaluation instead of growth potential.
\end{abstract}

Keywords: seasoned equity offering (SEO), insider trading, cumulative abnormal returns (CAR)

\section{Introduction}

Firms frequently issue seasoned equity offerings (SEOs) to raise their funds after going public. Based on the reports issued by Taiwan Stocks exchange (TSE) in 2015 (see Figure 1), the amount dollars of SEO increase during the bull stock market. On the contrary, when Taiwan stock market experiences the global financial crisis in 2008 and the Eurozone debt crisis in 2012, the amount dollars of SEO decrease.

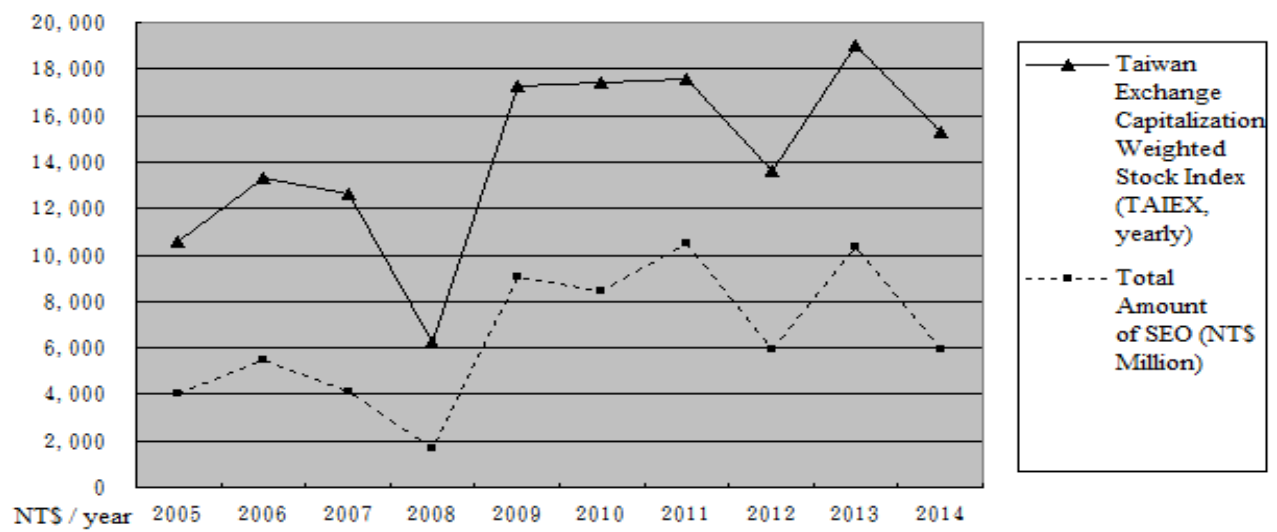

Figure 1. The comparison between Taiwan Exchange Capitalizations Weighted Stock Index (TAIEX) and the amount dollars of SEO issuing during 2005-2014

Note. The TAIEX from TSE covers all of the Taiwan listed stock for allowing investors to grab both overall market movement and different industrial sectors' performances.

In Taiwan, there are usually positive announcement effects around the SEO announcement (Lee \& Lin, 2001). Chen $\mathrm{Li}$ and Chen (2001) find that most of SEO issuers can increase the stock price on SEO announcement because of growth potential. Shu and Chiang (2012) also indicate that small firms can time the market to have higher announcement returns. Nonetheless, in U.S., DeAngelo, DeAngelo and Stulz (2010) document that the 
majority of SEOs do not improve the performances of the issuing firm since most of SEO issuers are not growing firms. Furthermore, most firms conducting SEO seem to meet short-term cash needs. If the firm fails to raise funds by SEO, it would run out of cash in the issuing year, which will lead to negative impacts on its long-term performances (Décamps, Mariotti, Rochet, \& Villeneuve, 2011) (Note 1).

In some developed countries, SEO has also played a very important role. For instance, in Switzerland, issuing firm with relatively small size announces an SEO for investment need. Then, the announcement can generate a positive effect on stock return (Dubois \& Jeanneret, 2000). In Sweden, the announcement of private placement usually has a positive reaction on stock price because it can reduce moral hazard costs, and reduce adverse selection costs. In Hong Kong, SEO affords an opportunity for insiders to trade profitably and maintains control right (Ching, Firth, \& Rui, 2006).

Insider trading is an important factor on SEO announcement. Ching et al. (2006) point out that insider buying can react more favorably to SEO announcement and has a positive price response on stock market. Specifically, insiders can communicate the superior information to outsiders around SEO event. Fidrmuc, Goergen and Renneboog (2006) argue that the director's purchases and sales in U.S. and U.K. can trigger significant immediate market reactions on announcement day. Shiue, Lin and Liu (2009) suggest that if the board of directors is independent and competent, they can efficiently decrease the magnitude of overvalued equity before firms issue SEO, which can exhibit the positive stock price reaction to SEO announcement. Although insider trading can obtain abnormal returns in SEO announcement, insider buying and selling have different information contents. While an insider buying conveys positive news to SEO, it is less clear what information an insider sale conveys since it may meet the liquidity needs of insider (Note 2).

In this paper, we calculate the abnormal returns of 506 issuing firms listed on the TSE from 2006-2014. We classify SEO firms by insider's purchases or sales to examine whether insider trading before announcement has the effect on CAR around SEO announcement. Following Ching et al. (2006), we define an insider as an officer, director or substantial shareholder (holding more than $10 \%$ of the nominal value of relevant share capital). Two measures of insider trading are defined as the number of individual transactions and the number of shares traded.

We find that there are negative announcement effects around the SEO announcement, which is not consistent with the argument that there are usually positive announcement effects around the SEO announcement in Taiwan (Lee \& Lin, 2001). Therefore, the motivation of SEO has changed from investment to overvaluation. Moreover, long-run abnormal returns following SEOs are negative, which is consistent with Loughran and Ritter (1995) and Spiess and Affleck-Graves (1995). Although there is net buying prior to SEO announcement, the outside investors still regard SEO announcement as a signal of overvaluation instead of growth potential.

The rest of the paper is organized as follows. Section 2 discusses the related literature about the effect of SEO announcement and insider trading. Section 3 describes the research methodology and descriptive statistics. Section 4 presents empirical results. Our conclusion is contained in Section 5.

\section{Literature Review}

There has been an on-going debate whether the firms issue SEO to strategically time the sale of overvalued stock or finance genuine corporate capital requirements. The characteristic of stock market in different country may also perform several stock price reactions. In the following literature review, this paper provides various effects of SEO announcement, long-term performance and insider trading review.

\subsection{The Effect of SEO Announcements}

\subsubsection{Negative Effect of SEO Announcements}

SEO announcements in the US are usually associated with significant negative effect. The prominent empirical study in the adverse selection model refers that SEO issues generally perform the stock price with high volumes and positive abnormal return before the SEO, but the stock price drops significantly on the announcement day (Lucas \& McDonald, 1990). Gombola, Lee, and Liu (1999) suggest that the insiders are usually the pure sellers significantly worse than the pure purchasers before announcements and knowingly selling overvalued shares by issuing SEO. Insider selling before SEO announcement can lead a negative effect on stock price. Kahle (2000) also supports that insiders trading on their own account would be a useful predictor of pre-announcement returns.

Chiang (2004) find there are negative abnormal returns when issuing SEOs on Taiwan markets. Lin (2004) indicates that the direction and magnitude of insiders trading to SEO in Taiwan would consider investment opportunities. If insiders sell their shares before SEOs announcement, the abnormal return on announcement would significantly lower than holding or buying of insiders. Insider trading before announcement is obviously correlation with stock price reaction of issuing firm. Jenter (2005) also propose that insider sales increase prior to 
the announcement due to overvaluation of stock price. Wang (2005) documents that manager may use accounting accruals to conceal poor performance before announcing SEOs. Testing the SEO firms in 1996-2004 periods from Taiwan stock market by using event study model, he finds that there is short-run overvaluation.

\subsubsection{Positive Effect of SEO Announcements}

Gombola et al. (1999) document that the impact of insider purchases on market reaction around SEO announcement are positive. Insiders can earn significant abnormal returns through firm conducting SEO; outsiders can buy shares following insiders' stock purchases, and thereby earn 3\% to $30 \%$ abnormal profits at least. Hill and Snell (1989) argue that more pre-offer institutional net selling is associated with a smaller SEO discount and better stock returns at announcement. Chen and Chan (1998) use Black-Scholes options pricing model to examine the domestic stock market, finding that the expected returns for investors who participate the SEOs is significantly high because the low of commission fee of balloting and offering price. Besides, offering price discount can positively effect the SEOs announcement. Chen (2005) think that in Taiwan, the date of announcement, resolution date of the board of directors, and the approved date of TSE typically signal a positive effect to stock market because of adopting bookbuilding. Using Fama-French model to measure CAR, Chen, $\mathrm{Li}$, and Chen (2001) find that the main reasons to result in the stock price upward are insider buying and growth potential.

\subsection{Long-Term Performance}

With respect to long-term performance, most studies find that SEO firms have the poor performances in the long run after the offer day and the negative stock price response after SEOs. Some of literatures present market timing fact of which records insider trading behavior to be market-timer characteristics. The negative abnormal return remains in the long run post-SEO. For instance, Loughran, Ritter, and Rydqvist (1994) mention the market timing is most prominent theoretical explanation for SEOs, which implies that insider waits for selling overvalued stocks when stock market conditions permit. The stock price of issuing firms exhibit overvaluation before an offering and underperforms afterwards. Landsberger (1998) proposes that managers knowingly exploit the windows of opportunities to sell new shares broadly in the market phenomenon when investors are overly optimistic about the value of stocks of SEOs. This phenomenon was eventually led the negative aftermarket performance in the post-SEO. Chiou (2003) imply that SEO can not effectively enhance the economic value and improve performance for issuing firm's operation. Issuing additional equity seems to explore the firm's future operating deterioration. Louis, Sun, and White (2010) also support that most of issuing firms are not the real-growth firm and the lower $\mathrm{M} / \mathrm{B}$ ratios. If firms with the poor condition loss an opportunity to issue equity, they will run out of the cash the year and furthermore lead the negative impact in the long-run performance.

\subsection{Insider Trading}

Karpoff and Lee (1991) examine insider trading before announcements of primary offerings of common stock, convertible debt, and straight debt, finding that insiders can signal private information to the market through trading in their personal account. Meanwhile, insider trading before announcing new security issue is correlated with stock price changes. Lee (1997) suggests that the true value of the firm based on informational asymmetry between insiders and outside investors could be observed by insiders trading pattern. If managers with superior information about the firm sell overvalued equity, market could regard as managers to be net sellers. Clarke, Dunbar, and Kahle (2001) observe insider trading between canceled and completed SEOs, proposing that completed SEOs exhibit a significant abnormal performance of approximately $-8 \%$ per year for the five years following the offering. If this underperformance is that insiders exploit opportunity to sell overvalued stock, insider trading would be a useful predictor of post-SEO returns. In repurchase literature, Bonaime and Ryngaert (2011) mention that managers make share repurchase announcements as a signal that the stock is valuable to the market, Firms with larger pre-announcement insider purchases experience larger buy-and-hold abnormal return (BHAR) during the year after the announcement.

\section{Research Methodology}

\subsection{Data Selection}

We use the SEO firms in TSE from January 2006 to December 2014 as a sample. The firms in finance and insurance industries are deleted due to their unique nature of financial reporting and survivorship bias (Kothari, Shanken, \& Sloan, 1992). The announcement date is defined as the resolution of board of director.

We define insiders as the members of the board of directors, the supervisory board, the top managers and shareholders who hold more than $10 \%$ of the stocks. We use the trading shares and number of transactions of insiders within six months before announcement date to compute insider purchases (or sells). Furthermore, when 
insiders purchase and sell stocks on the same month, we net the shares and number of transaction (e.g., a purchase of 10,000 shares and a sale of 5,000 shares are computed as a net purchase of 5,000 shares). We exclude the net of shares or transaction to equal zero. Following these adjustments, the sample covers 506 firms of insiders trading with respect to 256 trading shares and 249 numbers of transactions. The distribution of events is in Table 1. In SEO announcements, the number of net buying by number of transaction (200) is smaller than that of net selling (268). Because many insiders are compensated by options and restricted stocks, they are usually net sellers of company stocks.

\subsection{Variable Measurement and Definition}

The market-adjustment model is used to calculate AR. The announcement day is defined as day 0; the test period is chosen 2 days before to 5 days after the announcement day. The model is presented as follows.

$$
\begin{aligned}
A R_{j t} & =R_{j t}-R_{m t} \\
C A R_{i} & =\sum_{t=b}^{e} A R_{j t}
\end{aligned}
$$

where $R_{j t}$ is raw return of sample stock $\mathrm{j}$ on day $\mathrm{t} ; R_{m t}$ is market return of the value weighted index on day $\mathrm{t} ; A R_{j t}$ is abnormal return of sample stock $\mathrm{j}$ on day $\mathrm{t} ; C A R_{i}$ is the cumulative abnormal return of sample stock $\mathrm{i}$ during the event period; $b$ is the staring date and $e$ is ending date.

We perform different $t$ test to examine whether the average CAR for the trading share and number of transactions for insiders in SEO event varies significantly; we also estimates non-diagonal variance-covariance matrix as in Chiou (2003).

Table 1 . Sample distribution by year

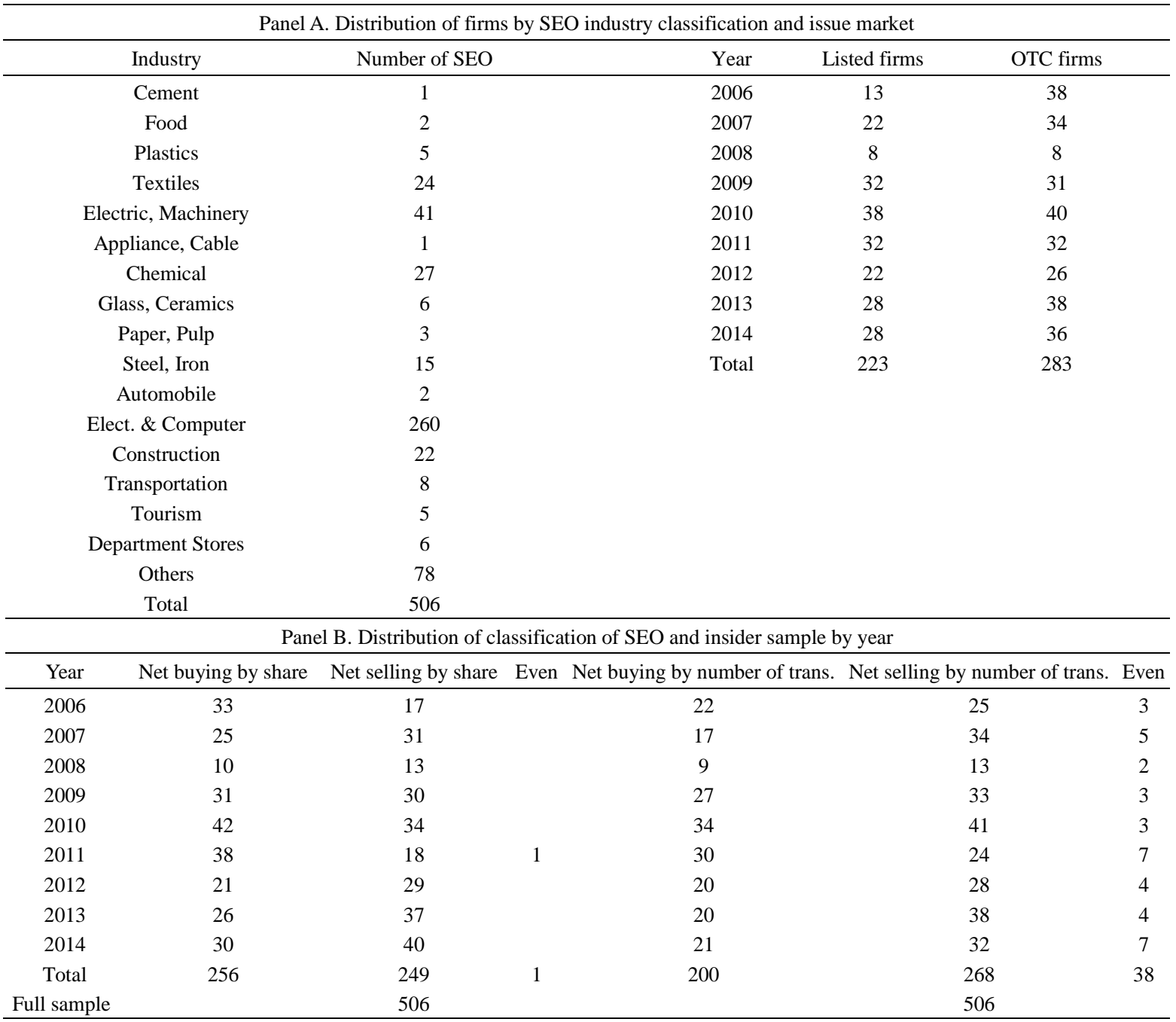




$$
\boldsymbol{T} \text { test }=\frac{\overline{C A R_{1}\left(t_{b}, t_{e}\right)}-\overline{C_{2}\left(R_{2}, t_{b}\right)}}{\sqrt{\frac{\operatorname{Var}\left(\overline{C A R_{1}\left(t_{e}, t_{b}\right)}\right)}{n_{1}}+\frac{\operatorname{Var}\left(\overline{C A R_{2}\left(t_{e}+t_{b}\right)}\right)}{n_{2}}}}
$$

We use the regression to measure the impact of insider trading on CAR around SEO. The independent variables are insider variable (ID), SEO firm size (size), Book-to-market (B/M), return on equity (ROE) and Leverage. Table 2 presents the definition of those variables and expectative impacts on CAR.

Table 2. Variables and definitions

\begin{tabular}{|c|c|c|}
\hline Variable names & Variable definitions & Expect results \\
\hline ID & $\begin{array}{l}\text { ID is the dummy variable that sets for measuring the classification of trading share/transaction } \\
\text { for net buying and net selling of insiders. If sample firm or insider trading is audited by } 1 \text {, } \\
\text { which is net buying of insiders for trading share/transaction, and is } 0 \text {, which is net selling of } \\
\text { insiders for trading share/transaction. }\end{array}$ & + \\
\hline SIZE & $\begin{array}{l}\text { Size is the market value of equity at the end of previous SEO year. It is calculated by the } \\
\text { number of common equity shares outstanding multiplied by the stock price. }\end{array}$ & + \\
\hline $\mathrm{B} / \mathrm{M}$ & $\begin{array}{l}\mathrm{B} / \mathrm{M} \text { is the natural logarithm of market-to-book ratio. It is defined as book value of equity } \\
\text { divided by the market value of equity at the end of previous SEO year. }\end{array}$ & + \\
\hline ROE & $\begin{array}{l}\text { ROE is the return on equity on previous year-end SEO. It is defined as net income divided by } \\
\text { equity at the end of prior year of SEO. }\end{array}$ & + \\
\hline Leverage & $\begin{array}{l}\text { Leverage is the debt-to-equity ratio. It is calculated by total liabilities divided by total asset at } \\
\text { the end of previous SEO year. }\end{array}$ & + \\
\hline
\end{tabular}

\subsection{Descriptive Statistics}

Table 3 reports summary statistics of trading shares and number of transactions for insider during SEO period. We utilize only $50 \%$ (higher than median) of the largest net buying (or net selling) because the larger net buying (or net selling) tend to have a much more substantial impact on CAR around SEO. Panel A shows the full sample for 228 trading share of insider. The net buying of insiders for 120 trading share, and net selling of insiders for 108 trading share are exhibited in Panels B and C, respectively. Panel D shows the full sample for 239 number of transactions for insider. Panels D and E present the 105 net buying and 133 net selling of number of transactions for insiders, respectively.

As showed in Panel A, the mean (median) of ID indicates that there are $52.63 \%(100 \%)$ of trading shares in SEO announcement. In Panel D, on average, there is $44.1 \%$ of number of transactions to trade for their SEO, indicating that there are approximately a half of insiders to take advantage of transitory "windows of opportunity" by issuing SEO. The mean of size is 8694.3 million USD, and the means of $\mathrm{B} / \mathrm{M}$ ratio, ROE, and leverage are $0.0008 \%, 9.57 \%$, and $47.95 \%$, respectively. With regarding to net buying and net selling of the trading shares and number of transactions in Panels B, C, E and F, the median size are 3944.5 million, 3967.5 million, 2690.0 million and 4073.0 million, respectively; suggesting that the firm size of net selling is larger than that of net buying. Meanwhile, the median B/M ratio in Panels B, C, E and F are $0.0006 \%$ and $0.0005 \%, 0.0007 \%$ and $0.0005 \%$, respectively. It indicates that $\mathrm{B} / \mathrm{M}$ ratio of net selling is smaller than that of net buying. The firms with large size and low M/B ratio take advantage of market overvaluation to conduct equity issues (Chen \& Cheng, 2008). Beneish and Vargus (2002) document that there are many alternatives for insiders to acquiring share (e.g., options, restricted stock award, performance plans awards, dividend unit awards) while share disposals occur mostly through SEO sales. Gao, Mao, and Ng (2015) also suggest that insiders may keep silent or no insider trading in SEO periods because they concern about shareholder litigation risk or large stock price drops after SEO event. Hence, we suggest that insiders may sell shares in announcement periods because of unfavorable prospects. 
Table 3. Summary statistics of variables by trading share and number of transactions on insider trading

\begin{tabular}{|c|c|c|c|c|c|c|}
\hline \multicolumn{7}{|c|}{ Panel A. Full sample of trading share } \\
\hline Variables & $\mathrm{N}$ & Mean & Median & S.D. & Min. & Max. \\
\hline ID & 228 & $52.63 \%$ & $100.00 \%$ & $50.04 \%$ & $0.00 \%$ & $100.00 \%$ \\
\hline SIZE (million) & 228 & 8694.3 & 3961 & 14180 & 53 & 111930 \\
\hline $\mathrm{B} / \mathrm{M}$ ratio & 228 & $0.0008 \%$ & $0.0005 \%$ & $0.0014 \%$ & $0.0000 \%$ & $0.0175 \%$ \\
\hline ROE & 228 & $9.5767 \%$ & $10.6150 \%$ & $18.7940 \%$ & $-78.6000 \%$ & $64.0100 \%$ \\
\hline Leverage & 228 & $0.4795 \%$ & $0.4961 \%$ & $0.1614 \%$ & $0.0086 \%$ & $0.8115 \%$ \\
\hline \multicolumn{7}{|c|}{ Panel B. Net buying of trading share } \\
\hline Variables & $\mathrm{N}$ & Mean & Median & S.D. & Min. & Max. \\
\hline ID & 120 & $100.00 \%$ & $100.00 \%$ & $0.00 \%$ & $100.00 \%$ & $100.00 \%$ \\
\hline SIZE (million) & 120 & 9176.2 & 3944.5 & 14423 & 53 & 111930 \\
\hline $\mathrm{B} / \mathrm{M}$ ratio & 120 & $0.0010 \%$ & $0.0006 \%$ & $0.0019 \%$ & $0.0001 \%$ & $0.0175 \%$ \\
\hline ROE & 120 & $8.5596 \%$ & $10.0150 \%$ & $18.0800 \%$ & $-78.6000 \%$ & $60.3000 \%$ \\
\hline Leverage & 120 & $0.5049 \%$ & $0.5186 \%$ & $0.1546 \%$ & $0.0757 \%$ & $0.8115 \%$ \\
\hline \multicolumn{7}{|c|}{ Panel C. Net selling of trading share } \\
\hline Variables & $\mathrm{N}$ & Mean & Median & S.D. & Min. & Max. \\
\hline ID & 108 & $0.00 \%$ & $0.00 \%$ & $0.00 \%$ & $0.00 \%$ & $0.00 \%$ \\
\hline SIZE (million) & 108 & 8158.8 & 3967.5 & 13952 & 409 & 111530 \\
\hline $\mathrm{B} / \mathrm{M}$ ratio & 108 & $0.0006 \%$ & $0.0005 \%$ & $0.0004 \%$ & $0.0000 \%$ & $0.0020 \%$ \\
\hline ROE & 108 & $10.7070 \%$ & $12.8700 \%$ & $19.5800 \%$ & $-63.3200 \%$ & $64.0100 \%$ \\
\hline Leverage & 108 & $0.4513 \%$ & $0.4604 \%$ & $0.1647 \%$ & $0.0086 \%$ & $0.7870 \%$ \\
\hline \multicolumn{7}{|c|}{ Panel D. Full sample of number of transactions } \\
\hline Variables & $\mathrm{N}$ & Mean & Median & S.D. & Min. & Max. \\
\hline ID & 239 & $44.11 \%$ & $0.00 \%$ & $49.75 \%$ & $0.00 \%$ & $100.00 \%$ \\
\hline SIZE (million) & 239 & 6958.1 & 3536 & 11092 & 53 & 111930 \\
\hline $\mathrm{B} / \mathrm{M}$ ratio & 239 & $0.0008 \%$ & $0.0005 \%$ & $0.0013 \%$ & $0.0001 \%$ & $0.0175 \%$ \\
\hline ROE & 239 & $10.9630 \%$ & $11.4550 \%$ & $16.6880 \%$ & $-78.6000 \%$ & $62.1400 \%$ \\
\hline Leverage & 239 & $0.4820 \%$ & $0.5063 \%$ & $0.1605 \%$ & $0.0086 \%$ & $0.7909 \%$ \\
\hline \multicolumn{7}{|c|}{ Panel E. Net buying of number of transactions } \\
\hline Variables & $\mathrm{N}$ & Mean & Median & S.D. & Min. & Max. \\
\hline ID & 105 & $100.00 \%$ & $100.00 \%$ & $0.00 \%$ & $100.00 \%$ & $100.00 \%$ \\
\hline SIZE (million) & 105 & 6047.8 & 2690 & 12574 & 53 & 111930 \\
\hline $\mathrm{B} / \mathrm{M}$ ratio & 105 & $0.0011 \%$ & $0.0007 \%$ & $0.0019 \%$ & $0.0001 \%$ & $0.0175 \%$ \\
\hline ROE & 105 & $10.6440 \%$ & $10.5500 \%$ & $13.4210 \%$ & $-52.5000 \%$ & $60.3000 \%$ \\
\hline Leverage & 105 & $0.5149 \%$ & $0.5328 \%$ & $0.1394 \%$ & $0.0757 \%$ & $0.7505 \%$ \\
\hline \multicolumn{7}{|c|}{ Panel F. Net selling of number of transactions } \\
\hline Variables & $\mathrm{N}$ & Mean & Median & S.D. & Min. & Max. \\
\hline ID & 133 & $0.00 \%$ & $0.00 \%$ & $0.00 \%$ & $0.00 \%$ & $0.00 \%$ \\
\hline SIZE (million) & 133 & 7676.7 & 4073 & 9755.1 & 276 & 52572 \\
\hline $\mathrm{B} / \mathrm{M}$ ratio & 133 & $0.0006 \%$ & $0.0005 \%$ & $0.0005 \%$ & $0.0001 \%$ & $0.0031 \%$ \\
\hline ROE & 133 & $11.2140 \%$ & $12.9400 \%$ & $18.9200 \%$ & $-78.6000 \%$ & $62.1400 \%$ \\
\hline Leverage & 133 & $0.4561 \%$ & $0.4646 \%$ & $0.1714 \%$ & $0.0086 \%$ & $0.7909 \%$ \\
\hline
\end{tabular}

Note. We utilize only 50\% (higher than median) of the largest net buying (or net selling) for the larger net buying (or net selling) tend to have a much more substantial impact on CAR around SEO. The sample contains 228 trading share in Panel A and 239 numbers of transactions in Panel D on insider trading during SEO period. We classifies shares of insider trading into 120 net buying in Panel B and 108 net selling in Panel C; classified number of transactions of insider trading into 105 net buying in Panel E and net selling in Panel F.

\section{Empirical Results}

Table 4 reports the summary statistics of CAR for the full sample on trading shares and number of transactions in two sets of trading measures (net buying and net selling). It shows that CARs on trading shares and number of transactions all exhibit the negative mean value, which are $-124.93 \%$ of mean net buying and $-9.83 \%$ of mean net selling for trading share in Panel A, $-112.32 \%$ of mean net buying and $-4.18 \%$ of mean net selling for number of transactions in Panel B, respectively. The result that the announcement effects around the SEO announcement 
are negative is not consistent with the argument that there are usually positive announcement effects around the SEO announcement in Taiwan (Lee \& Lin, 2001). Therefore, the motivation of SEO has changed from investment to overvaluation.

Table 4. Summary statistics for CAR $(-2,5)$, relative to classification of SEO firm and insider trading

\begin{tabular}{cccc}
\hline \multicolumn{4}{c}{ Panel A: Classification with Share on insider trading } \\
\hline Mean & Full sample & Net buying & Net selling \\
Median & -0.7041 & -1.2493 & -0.0983 \\
S.D & -1.4674 & -1.6938 & -1.2406 \\
Min. & 7.8811 & 7.6474 & 8.1256 \\
Max. & -24.087 & -20.254 & -24.087 \\
\hline \multicolumn{4}{c}{ Panel B: Classification with number of Transactions on insider trading } \\
\hline Mean & Full sample & Net buying & 25.541 \\
Median & -0.5188 & -1.1232 & Net selling \\
S.D & -1.3138 & -1.6153 & -0.0418 \\
Min. & 7.8631 & 7.7802 & -0.7428 \\
Max. & -24.087 & -20.254 & 7.9245 \\
\hline
\end{tabular}

Note. This table shows the summary statistic of CAR(-2,5) for SEO firms. Panel A presents the full sample and classification with Share on insider trading; Panel B shows the full sample and classification with number of Transactions on insider trading.

Table 5 provides average CAR for net buying and net selling surrounding SEO announcement. Nevertheless, Panel A shows that insider purchases by shares have negative response on average CAR, which is $-129 \%$ and significant at $5 \%$ significant level in event window $(-2,5)$. Insider selling by shares also performs negative and insignificant CAR in event window $(-2,5)$, which is $-12.11 \%$. Average CARs for net buying are all negative during SEO announcement. Similarly, in Panel B of Table 5, the average CAR of insider purchase for number of transactions in event window $(-2,5)$ is negative $(-119 \%)$ and significant at $10 \%$ level. Meanwhile, the average CAR of the insider selling is $-12.11 \%$. In sum, the results of the different $\mathrm{T}$ test by shares and number of transactions show the average CARs for net buying are less than those for net selling around announcement period. Figures 2 and 3 show that the CARs for insider trading by trading share and trading transaction are negative during SEO announcement. Thus, although there is net buying prior to SEO announcement, the outside investors still regard SEO announcement as a signal of overvaluation instead of growth potential.

Table 5. Average CAR difference T test of insider trading between trading share and trading transaction

\begin{tabular}{cccc}
\hline & \multicolumn{2}{c}{ Panel A: Trading Share of insider } & \\
\hline Event window & Net buying & Net selling & Difference \\
\hline$(-2,0)$ & -0.4301 & 0.5144 & $-1.4998^{*}$ \\
& $(0.1567)$ & $(0.1352)$ & $(0.0674)$ \\
$(-2,5)$ & $-1.2978^{* *}$ & -0.1211 & -1.2052 \\
& $(0.0319)$ & $(0.4300)$ & $(0.1146)$ \\
$(-1,0)$ & $-0.4874^{*}$ & 0.2745 & $-1.5633^{*}$ \\
& $(0.0586)$ & $(0.2338)$ & $(0.0596)$ \\
$(-1,1)$ & $-0.8642^{* *}$ & 0.1879 & $-1.6866^{* *}$ \\
& $(0.0175)$ & $(0.3462)$ & $(0.0464)$ \\
$(-1,5)$ & $-1.3551^{* *}$ & -0.3611 & -1.0877 \\
& $(0.0199)$ & $(0.2867)$ & $(0.1388)$ \\
$(0,1)$ & $-0.5517^{*}$ & 0.2472 & $-1.5411^{*}$ \\
& $(0.0574)$ & $(0.2608)$ & $(0.0622)$ \\
$(0,3)$ & $-1.0595^{* *}$ & -0.2161 & -1.1374 \\
& $(0.0197)$ & $(0.3445)$ & $(0.1282)$ \\
$(0,5)$ & $-1.0425^{*}$ & -0.3018 & -0.8267 \\
& $(0.0545)$ & $(0.3138)$ & $(0.2045)$ \\
\hline
\end{tabular}




\begin{tabular}{cccc}
\hline & \multicolumn{2}{c}{ Panel B: Trading number of transactions of insider } & \\
\hline Event window & Net buying & Net selling & Difference \\
\hline$(-2,0)$ & $-0.5553^{* *}$ & 0.5144 & $-1.4998^{*}$ \\
& $(0.0473)$ & $(0.1352)$ & $(0.0674)$ \\
$(-2,5)$ & $-1.1910^{*}$ & -0.1211 & -1.2052 \\
& $(0.0569)$ & $(0.4300)$ & $(0.1146)$ \\
$(-1,0)$ & $-0.7960^{* * *}$ & 0.2745 & $-1.5633^{*}$ \\
& $(0.0011)$ & $(0.2338)$ & $(0.0596)$ \\
$(-1,1)$ & $-0.8929^{* * *}$ & 0.1879 & $-1.6866^{* *}$ \\
& $(0.0083)$ & $(0.3462)$ & $(0.0464)$ \\
$(-1,5)$ & $-1.4317^{* *}$ & -0.3611 & -0.6893 \\
& $(0.0254)$ & $(0.2867)$ & $(0.2456)$ \\
$(0,1)$ & $-0.5889^{* *}$ & 0.2472 & $-1.5411^{*}$ \\
& $(0.0352)$ & $(0.2608)$ & $(0.0622)$ \\
$(0,3)$ & $-0.9857^{* *}$ & -0.2161 & -1.1374 \\
& $(0.0499)$ & $(0.3445)$ & $(0.1282)$ \\
$(0,5)$ & $-1.1277^{*}$ & -0.3018 & -0.8267 \\
& $(0.0635)$ & $(0.3138)$ & $(0.2045)$ \\
\hline
\end{tabular}

Note. This table presents the average CAR difference $\mathrm{T}$ test between trading share and number of transactions of insider trading during SEO announcement period. ***,**, and $*$ denote significant at $1 \%, 5 \%$, and $10 \%$ level.

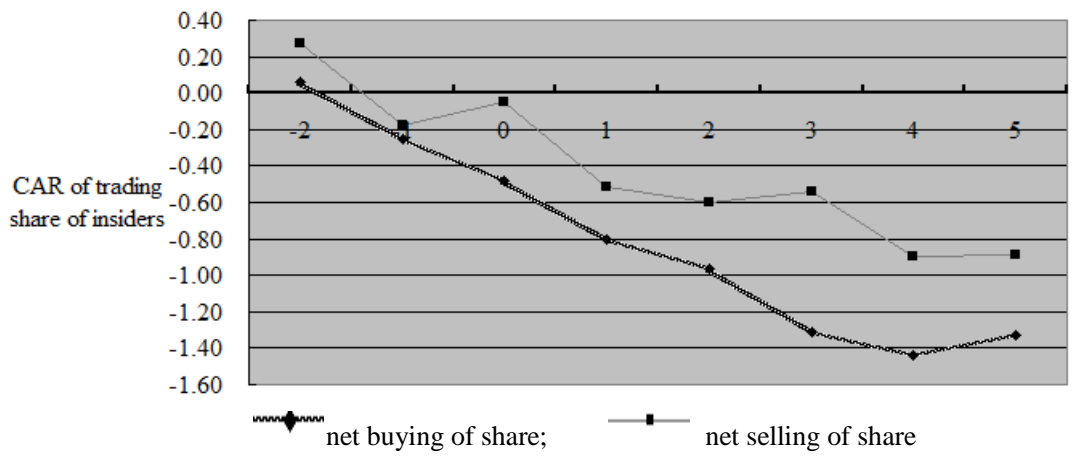

Figure 2. Cumulative abnormal return of trading share of insiders

Note. The figure shows the comparison of CAR for net buying and net selling for insiders.

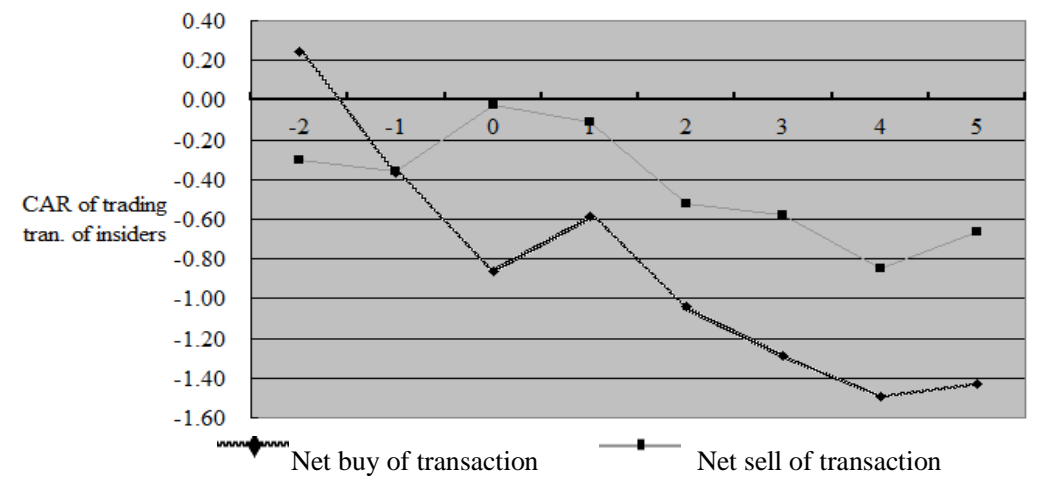

Figure 3. Cumulative abnormal return of number of trading transaction for insiders

Note. The figure shows the comparison of CAR for net buying and net selling on number of transactions for insiders.

Shu and Chiang (2012) also mention that insider trading allows information (such as SEO event) to be absorbed into different groups of insiders, such as director's trade. According to the information hierarchy hypothesis, insiders who are more familiar with the day-to-day operations of the firm trade on more valuable information. In order to examine whether well-informed insider's trade can actually influence the effect of SEO, we narrow the range of insiders to directors. Table 6 presents the average CAR for those directors. According to Fidrmuc, 
Goergen, and Renneboog (2006), trades of directors contain more information than those of large shareholders. Moreover, the director sale may convey unfavorable information about the firm's prospects whereas director buy may convey positive information. Although director trading on trading share in Panel A also show a negative abnormal return during announcement period (in event window $(-2,5)$ ), the average CAR for net buying is insignificantly greater than that for net selling. In contrast, number of transactions for director in Panel B show $-211.6 \%$ on net buying and significant at $5 \%$ level; $56.7 \%$ on net selling in event window $(-2,5)$. The average CAR for net buying is significantly less than that for net selling at 5\% level. Therefore, we argue that the impacts of director' purchases and sales on CAR around SEO announcement are similar with those of insiders, which is inconsistent with the information hierarchy hypothesis.

Table 6. Average CAR difference $\mathrm{T}$ test for director trading between trading share and number of transactions

\begin{tabular}{|c|c|c|c|}
\hline \multicolumn{4}{|c|}{ Panel A: Trading Share of the director trading } \\
\hline Event window & Net buying & Net selling & Difference \\
\hline \multirow[t]{2}{*}{$(-2,0)$} & -0.0761 & -0.4079 & $1.9316^{* *}$ \\
\hline & $(0.3991)$ & $(0.1349)$ & $(0.0271)$ \\
\hline \multirow[t]{2}{*}{$(-2,5)$} & -0.4469 & $-1.3182 * *$ & 1.0746 \\
\hline & $(0.2025)$ & $(0.0159)$ & $(0.1417)$ \\
\hline \multirow[t]{2}{*}{$(-1,0)$} & 0.1836 & -0.3752 & $1.3366^{*}$ \\
\hline & $(0.2582)$ & $(0.1128)$ & $(0.0911)$ \\
\hline \multirow[t]{2}{*}{$(-1,1)$} & -0.1461 & $-0.8372 * *$ & 1.2652 \\
\hline & $(0.3423)$ & $(0.0217)$ & $(0.1034)$ \\
\hline \multirow[t]{2}{*}{$(-1,5)$} & $-0.8635^{* *}$ & $-1.2855^{* *}$ & 0.5438 \\
\hline & $(0.0466)$ & $(0.0145)$ & $(0.2934)$ \\
\hline \multirow[t]{2}{*}{$(0,1)$} & -0.0761 & $-0.6842^{* *}$ & $1.3453^{*}$ \\
\hline & $(0.3991)$ & $(0.0230)$ & $(0.0897)$ \\
\hline \multirow[t]{2}{*}{$(0,3)$} & $-0.8298 * *$ & $-0.6545^{*}$ & -0.2748 \\
\hline & $(0.0305)$ & $(0.0792)$ & $(0.3917)$ \\
\hline \multirow[t]{2}{*}{$(0,5)$} & $-0.7935^{*}$ & $-1.1325^{* *}$ & 0.4533 \\
\hline & 0.0562 & $(0.0221)$ & $(0.3253)$ \\
\hline \multicolumn{4}{|c|}{ Panel B: Number of transactions of the director trading } \\
\hline Event window & Net buying & Net selling & Difference \\
\hline \multirow[t]{2}{*}{$(-2,0)$} & $-0.5454 *$ & 0.0774 & $0.7696 * *$ \\
\hline & $(0.0774)$ & $(0.0468)$ & $(0.0138)$ \\
\hline \multirow[t]{2}{*}{$(-2,5)$} & $-2.1165 * *$ & 0.0135 & 0.567 \\
\hline & $(0.0135)$ & $(0.2075)$ & $(0.0114)$ \\
\hline \multirow[t]{2}{*}{$(-1,0)$} & $-0.482 *$ & 0.0651 & 0.1548 \\
\hline & $(0.0651)$ & $(0.3405)$ & $(0.0977)$ \\
\hline \multirow[t]{2}{*}{$(-1,1)$} & $-1.2982 * * *$ & 0.0061 & -0.3421 \\
\hline & $(0.0061)$ & $(0.2213)$ & $(0.0787)$ \\
\hline \multirow[t]{2}{*}{$(-1,5)$} & $-2.0530 * *$ & 0.0156 & -0.0477 \\
\hline & $(0.0156)$ & $(0.4701)$ & $(0.0392)$ \\
\hline \multirow[t]{2}{*}{$(0,1)$} & $-1.2005 * * *$ & 0.0083 & -0.2468 \\
\hline & $(0.0083)$ & $(0.2351)$ & $(0.0562)$ \\
\hline \multirow[t]{2}{*}{$(0,3)$} & $-2.1563^{* * * *}$ & 0.0024 & -0.3765 \\
\hline & $(0.0024)$ & $(0.2325)$ & $(0.0254)$ \\
\hline \multirow[t]{2}{*}{$(0,5)$} & $-1.9553 * *$ & 0.0203 & 0.0474 \\
\hline & $(0.0203)$ & $(0.4689)$ & $(0.0378)$ \\
\hline
\end{tabular}

Note. This table shows the average CAR difference $\mathrm{T}$ test between trading share and number of transactions of director trading during SEO announcement period. ***,**, and $*$ denote significant at $1 \%, 5 \%$, and $10 \%$ level.

Moreover, Chiang (2004) report that the insider trading on the TWSE may not trade for short-term profits but rather for some other long-term objectives. Because insiders may be afraid of illegal penalties around the time of price-sensitive announcement, they do not trade or delay a significant amount of trading. Following Chiang (2004), we stretch the length of time measurement to one-year before and after an announcement. In Table 7, we set the event window from one year before to one year after announcement day as the observation period to 
examine whether there are different impacts of net buying and net selling on CAR. Panel A presents that the CAR of insider purchase by trading share increases from $71.09 \%$ (in event window $(-360,0)$ ) to $1530.5 \%$ (in event window $(-30,0)$ ) before an announcement; the CAR of insider buying on number of transactions (from $82.51 \%$ in event window $(-360,0)$ to $3082.6 \%$ in event window $(-30,0)$ ) also shows the same results by trading share. By contrast, the insider selling on trading share is obtained a negative CAR from $-160.4 \%$ in event window $(-360,0)$ to $-6.3 \%$ in event window $(-60,0)$; the insider selling on number of transactions also receives negative CAR $(-206.7 \%$ in event window $(-360,0)$ and $-2.08 \%$ in event window $(-60,0)$ respectively). It shows that there is a strong intention for insiders to buy SEO shares before 180 days of announcement day, because CARs is positive and significant at $10 \%$ level. In particular, in post-announcement year for both trading share and number of transactions whenever is net buying and net selling, the CAR in Panel B is negative over one year, and is significant at $10 \%$ level one year after announcement. The negative long-run abnormal returns following SEOs are consistent with Loughran and Ritter (1995) and Spiess and Affleck-Graves (1995). Therefore, we argue that insiders should avoid trading over the announcement period. According to Chiang (2004), insiders may be afraid illegal or market penalties around the time of price-sensitive announcement. Moreover, Gao et al. (2015) also suggest that insiders may not trade over a period of 12 months when firms issue common stocks due to trading constraints or litigation risk, and then external investors may interpret that insiders' lack of buying over announcement period is associated with bad news.

Table 7. Abnormal return (AR) and Cumulative abnormal return (CAR) by trading share and number of transactions of insider for year

\begin{tabular}{|c|c|c|c|c|c|c|}
\hline \multicolumn{7}{|c|}{ Panel A. CAR before SEO announcements } \\
\hline \multirow[b]{2}{*}{ Event window } & \multicolumn{2}{|c|}{ Full sample } & \multicolumn{2}{|c|}{ Net buy } & \multicolumn{2}{|c|}{ Net sell } \\
\hline & Trading Share & Number of trans. & Trading Share & Number of trans. & Trading Share & Number of trans. \\
\hline \multirow[t]{2}{*}{$(-360,0)$} & $0.5252 * *$ & 0.1921 & $0.7109 * *$ & $0.8251 * * *$ & -1.6049 & -2.0678 \\
\hline & $(0.0113)$ & $(0.9266)$ & $(0.0352)$ & $(0.0044)$ & $(0.6766)$ & $(0.5748)$ \\
\hline \multirow[t]{2}{*}{$(-180,0)$} & 0.097 & $11.2516^{* * *}$ & $12.2793 * * *$ & $12.3719 * * *$ & -0.0347 & 0.3418 \\
\hline & $(0.5865)$ & $(0.0003)$ & $(0.0021)$ & $(0.0043)$ & $(0.8927)$ & $(0.2058)$ \\
\hline \multirow[t]{2}{*}{$(-60,0)$} & 0.1716 & 23.9303 & $14.2736 * * *$ & 26.5842 & -0.0631 & -0.0208 \\
\hline & $(0.3416)$ & $(0.0001)$ & $(0.0001)$ & $(0.0001)$ & $(0.8106)$ & $(0.9267)$ \\
\hline \multirow[t]{2}{*}{$(-30,0)$} & $3.5942 * * *$ & $0.2712 * *$ & $15.3058 * * *$ & 30.8267 & 0.2346 & 0.1542 \\
\hline & $(0.0013)$ & $(0.0251)$ & $(0.0004)$ & $(0.0001)$ & $(0.3254)$ & $(0.5418)$ \\
\hline \multicolumn{7}{|c|}{ Panel B. CAR after SEO announcements } \\
\hline \multirow[t]{2}{*}{$(0,30)$} & $-1.9058 * *$ & 0.2087 & -1.8043 & -1.0761 & -1.9515 & $-2.0354 *$ \\
\hline & $(0.027)$ & $(0.7734)$ & $(0.1178)$ & $(0.3692)$ & $(0.1487)$ & $(0.0788)$ \\
\hline \multirow[t]{2}{*}{$(0,60)$} & -1.4431 & -0.6902 & -1.9769 & -1.5544 & -1.243 & $-4.2663 * * *$ \\
\hline & $(0.2237)$ & $(0.4756)$ & $(0.2785)$ & $(0.402)$ & $(0.4813)$ & $(0.0041)$ \\
\hline \multirow[t]{2}{*}{$(0,180)$} & -9.9479 & $-5.6332 * * *$ & $-7.6706^{* *}$ & $-6.9161 * *$ & $-12.3106^{* * *}$ & -16.3794 \\
\hline & $(0.0001)$ & $(0.0013)$ & $(0.0187)$ & $(0.0275)$ & $(0.0001)$ & $(0.0001)$ \\
\hline \multirow[t]{2}{*}{$(0,360)$} & -19.2208 & -13.6676 & $-20.2871 * * *$ & $-15.7675^{* * *}$ & $-18.1449 * * *$ & -26.0353 \\
\hline & $(0.0001)$ & $(0.0001)$ & $(0.0001)$ & $(0.0002)$ & $(0.0001)$ & $(0.0001)$ \\
\hline
\end{tabular}

Note. This table presents cumulative abnormal returns (CAR) of insider trading on trading share and number of transactions prior to 1 year of SEO announcement to 1 year of SEO announcement after. Besides, *significant at $\mathrm{P}<0.1$, **significant at $\mathrm{P}<0.05$, and ***significant at $\mathrm{P}<0.01$.

In Table 8, we run the regression to examine whether the CAR is affected by insider trading in net buying and net selling based on trading share and number of transactions. Based on Fidrmuc et al. (2006), we control for other variables (size, B/M ratio, ROE and leverage) that may affect the CAR. Panel A (B) shows the regression of insider trading in net buying and net selling by trading share (number of transaction) on CAR. In these regressions, we define ID to equal 1 when the insiders are net buying, and zero otherwise. In Panels A and B, we find that the coefficients for insider trading are negative when we control size, B/M ratio, ROE and leverage of variables, except in event window $(-2,0)$ of number of transactions traded in Panel B. The results imply that insiders seem to trade not for signal reason. For example, Fidrmuc et al. (2006) suggest that insiders trade due to liquidity needs rather than growth factor. Further, although the outside investors observe there is net buying prior to SEO announcement, they still regard SEO announcement as a signal of overvaluation instead of growth potential. Thus, the market reactions to SEO announcement are negative. 
Table 8. The regressions of classification on cumulative abnormal returns

\begin{tabular}{|c|c|c|c|c|c|c|c|}
\hline \multicolumn{8}{|c|}{ Panel A: Trading share of insider } \\
\hline & Constant & ID & Size & $\mathrm{B} / \mathrm{M}$ ratio & ROE & Leverage & Adj. R-sq \\
\hline \multirow[t]{2}{*}{$\mathrm{CAR}(-2,0)$} & 1.4491 & $-1.1575^{*}$ & 0.00001 & 147.37 & $-0.0371 * * *$ & -1.2158 & 0.0139 \\
\hline & $(0.1961)$ & $(0.0914)$ & $(0.5360)$ & $(0.5413)$ & $(0.0415)$ & $(0.5656)$ & \\
\hline \multirow[t]{2}{*}{$\operatorname{CAR}(-2,5)$} & -0.2290 & -1.3790 & -0.000002 & 496.51 & -0.0103 & 0.3246 & -0.0038 \\
\hline & $(0.8964)$ & $(0.2000)$ & $(-0.4642)$ & $(0.1910)$ & $(0.7170)$ & $(0.9222)$ & \\
\hline \multirow{2}{*}{$\operatorname{CAR}(-1,0)$} & 0.9401 & $-1.0091^{*}$ & 0.000002 & 146.97 & $-0.0271 *$ & -0.9870 & 0.0191 \\
\hline & $(0.2803)$ & $(0.0585)$ & $(0.2725)$ & $(0.4334)$ & $(0.0553)$ & $(0.5485)$ & \\
\hline \multirow[t]{2}{*}{$\operatorname{CAR}(-1,1)$} & 0.9278 & $-1.2830^{*}$ & 0.000003 & 249.75 & -0.0204 & -1.1844 & 0.0048 \\
\hline & $(0.4093)$ & $(0.0627)$ & $(0.8750)$ & $(0.3030)$ & $(0.2626)$ & $(0.5773)$ & \\
\hline \multirow[t]{2}{*}{ CAR(-1,5) } & -0.7380 & -1.2306 & -0.000002 & 496.10 & -0.0003 & 0.5534 & -0.0050 \\
\hline & $(0.6516)$ & $(0.2184)$ & $(0.5307)$ & $(0.1599)$ & (0.9904) & $(0.8578)$ & \\
\hline \multirow[t]{2}{*}{$\operatorname{CAR}(0,1)$} & 0.5901 & $-0.9900^{*}$ & 0.000002 & 224.29 & -0.0018 & -0.7849 & -0.0037 \\
\hline & (0.5309) & $(0.0862)$ & $(0.8815)$ & $(0.2697)$ & (0.9013) & $(0.6593)$ & \\
\hline \multirow[t]{2}{*}{$\operatorname{CAR}(0,3)$} & -0.8232 & -1.0540 & -0.000002 & 322.91 & 0.0120 & 1.2240 & -0.0030 \\
\hline & $(0.5433)$ & $(0.2035)$ & $(0.3068)$ & $(0.2692)$ & $(0.5824)$ & $(0.6326)$ & \\
\hline \multirow[t]{2}{*}{$\operatorname{CAR}(0,5)$} & -1.0757 & -0.9377 & -0.000002 & 470.65 & 0.0182 & 0.9529 & -0.0063 \\
\hline & $(0.5032)$ & $(0.3398)$ & $(0.5091)$ & $(0.1749)$ & $(0.4843)$ & $(0.7537)$ & \\
\hline \multicolumn{8}{|c|}{ Panel B: number of transactions traded of insider } \\
\hline \multirow[t]{2}{*}{$\operatorname{CAR}(-2,0)$} & 0.0992 & $0.9420^{*}$ & 0.00002 & 121.79 & -0.0023 & -1.3560 & 0.0007 \\
\hline & $(0.9114)$ & $(0.0782)$ & $(0.2239)$ & $(0.6833)$ & $(0.8739)$ & $(0.4158)$ & \\
\hline \multirow[t]{2}{*}{$\operatorname{CAR}(-2,5)$} & -1.1353 & -1.1605 & 0.000006 & -44.780 & 0.0115 & 2.0333 & -0.0144 \\
\hline & $(0.5238)$ & $(0.2756)$ & $(0.8560)$ & $(0.9079)$ & $(0.7173)$ & $(0.5415)$ & \\
\hline \multirow[t]{2}{*}{$\operatorname{CAR}(-1,0)$} & -0.0410 & $-1.0143^{* *}$ & $0.00004 * *$ & -54.748 & -0.0139 & 0.4536 & 0.0221 \\
\hline & $(0.9602)$ & $(0.0398)$ & $(0.0311)$ & $(0.7596)$ & $(0.3466)$ & $(0.7681)$ & \\
\hline \multirow[t]{2}{*}{$\operatorname{CAR}(-1,1)$} & 0.3587 & $-1.1275^{*}$ & 0.00003 & 166.13 & -0.0012 & 0.5054 & 0.0011 \\
\hline & $(0.7397)$ & $(0.0814)$ & $(0.1805)$ & $(0.4795)$ & $(0.9471)$ & $(0.8023)$ & \\
\hline \multirow[t]{2}{*}{$\operatorname{CAR}(-1,5)$} & -1.4723 & -1.3052 & 0.00005 & 185.8 & 0.0199 & 1.6091 & -0.0111 \\
\hline & $(0.3836)$ & $(0.1963)$ & $(0.7506)$ & $(0.6130)$ & $(0.5114)$ & (0.6104) & \\
\hline \multirow[t]{2}{*}{$\operatorname{CAR}(0,1)$} & -0.1613 & $-0.9426^{*}$ & 0.00001 & 280.99 & 0.0083 & 0.0808 & 0.0007 \\
\hline & $(0.8583)$ & $(0.0817)$ & $(0.4903)$ & $(0.1536)$ & $(0.6080)$ & $(0.9618)$ & \\
\hline \multirow[t]{2}{*}{$\operatorname{CAR}(0,3)$} & -1.2911 & -1.0305 & -0.00001 & 201.24 & 0.0226 & 1.7716 & -0.0099 \\
\hline & $(0.3595)$ & $(0.2210)$ & $(0.7436)$ & $(0.5111)$ & $(0.3706)$ & $(0.5011)$ & \\
\hline \multirow[t]{2}{*}{$\operatorname{CAR}(0,5)$} & -1.2749 & -1.1202 & -0.00007 & 300.663 & 0.0295 & 1.1845 & -0.0106 \\
\hline & $(0.4461)$ & $(0.2626)$ & $(0.8631)$ & $(0.4087)$ & $(0.3258)$ & $(0.7048)$ & \\
\hline
\end{tabular}

Note. The main independent variables are the dummy about classification of trading share of insider in Panel A and the dummy about classification of number of transactions in Panel B. The sample period is from the 2006-2012. The regression dependent variable is CAR. The independent variables, which are ID, Size, B/M ratio, ROE, Leverage, are defined in Table 2. *, **, and *** indicate significant levels at the $10 \%, 5 \%$, and $1 \%$ level.

\section{Conclusion}

This study explores whether insider trading in the six months prior to announcement day has an influence on CAR around SEO announcement. We find that there are negative announcement effects around the SEO announcement, which is not consistent with the argument that there are usually positive announcement effects around the SEO announcement in Taiwan (Lee \& Lin, 2001). Therefore, the motivation of SEO has changed from investment to overvaluation. Moreover, long-run abnormal returns following SEOs are negative, which is consistent with Loughran and Ritter (1995) and Spiess and Affleck-Graves (1995). Although there is net buying prior to SEO announcement, the outside investors still regard SEO announcement as a signal of overvaluation instead of growth potential. Thus, insider buying is not a good signal to show the firms' future prospect since they may trade on other information (such as liquidity needs). Therefore, beside insider trading, investors should take into account the other variables, such as multiple trading or transaction value. We also suggest that the Financial Supervisory Commission (FSC) should monitor the long-term returns on insider trading.

\section{References}

Amel-Zadeh, A., Faasse, J., \& Lotz, J. (2016). Are all insider sales created equal? New evidence from form 4 footnote disclosures. Working Paper, University of Oxford.

Beneish, M. D., \& Vargus, M. E. (2002). Insider trading, earnings quality, and accrual mispricing. The Accounting Review, 77, 755-791. https://doi.org/10.2139/ssrn.275985

Bonaime, A., \& Ryngaert, M. D. (2011). Insider trading and share repurchases: Do insiders and firms trade in the 
same direction? Journal of Corporate Finance, 22, 35-53. https://doi.org/10.2139/ssrn.1361738

Chen, A., Li, W. L., \& Chen, R. C. Y. (2001). The announcement effect of seasoned equity offerings with respect to the growth potential and insider trading. Journal of Financial Studies, 9, 1-25. https://doi.org/10.6545/JoFS.2001.9(1).1

Chen, A. S., \& Cheng, L. Y. (2008). Seasoned equity offerings, market timing and long-run performance. Working Paper, National Chung Cheng University.

Chen, S. Y., \& Chan, Y. C. (1998). An empirical study on seasoned equity offering price of Taiwan listed companies. Working Paper, National Taiwan University.

Chiang, I. S. (2004). The long-run return of IPO in Taiwan. Working Paper, National Central University.

Ching, K. M. L., Firth, M., \& Rui, O. M. (2006). The information content of insider trading around seasoned equity offerings. Pacific Basin Finance Journal, 14, 91-117. https://doi.org/10.1016/j.pacfin.2005.07.002

Chiou, J. R. (2003). A Study on the Stock Behavior of Seasoned Equity Offerings Based on the Characteristics of Cross-Strait Stock Markets. Working Paper, National Cheng Kung University.

Chiu J.R. (2005). Initial public offerings, first seasoned equity offerings, and stock performance: an emphasis on the offering timing. Working Paper, National Cheng Kung Universty.

Clarke, J., Dunbar, C., \& Kahle, K. M. (2001). Long-run performance and insider trading in completed and canceled seasoned equity offerings. Journal of Financial and Quantitative Analysis, 36, 415-430. https://doi.org/10.2307/2676218

DeAngelo, H., DeAngelo, L., \& Stulz, R. M. (2010). Seasoned equity offerings, market timing, and the corporate lifecycle. Journal of Financial Economics, 95, 275-295.https://doi.org/10.2139/ssrn.1000441

Décamps, J. P., Mariotti, T., Rochet, J. C., \& Villeneuve, S. (2011). Free cash flow, issuance costs, and stock prices. Journal of Finance, 66, 1501-1544. https://doi.org/10.2139/ssrn.1097648

Dong, M., Hirshleifer, D., \& Teoh, S. (2012). Overvalued equity and financing decision. Review of Financial Studies, 25, 3645-3683. https://doi.org/10.2139/ssrn.1874726

Dubois, M., \& Jeanneret, P. (2000). The long-run performance of seasoned equity offerings with rights evidence from the Swiss market. Working Paper, Neuchatel University. https://doi.org/10.2139/ssrn.239873

Evgeniou, T., Junqué de Fortuny, E., Nassuphis, N., \& Vermaelen, T. (2017). Volatility and the Buyback Anomaly. Working Paper, INSEAD.

Fama, E. F., \& French, K. R. (1993). Common risk factors in the returns of stocks and bonds. Journal of Financial Economics, 33, 3-56. https://doi.org/10.1016/0304-405X(93)90023-5

Fama, E. F., \& French, K. R. (2015). Dissecting anomalies with a five-factor model. Fama-Miller Working Paper. Fidrmuc. https://doi.org/10.1093/rfs/hhv043

J. P., Goergen, M., \& Renneboog, L. (2006). Insider trading, news releases, and ownership concentration. Journal of Finance, 61, 2931-2973. https://doi.org/10.1111/j.1540-6261.2006.01008.x

Fu, F., \& Huang, S. (2015). The persistence of long-run abnormal returns following stock repurchases and offerings. Management Science (Forthcoming). https://doi.org/10.1287/mnsc.2015.2150

Gao, G., Mao, Q., \& Ng, D. T. (2015). The sound of silence: What do we know when insiders do not trade? Working Paper, Cornell University. https://doi.org/10.2139/ssrn.2167998

Gombola, M. J., Lee, H. W., \& Liu, F. Y. (1999). Further evidence on insider selling prior to seasoned equity offering announcements: The role of growth opportunities. Journal of Business Finance \& Accounting, 26, 621-649. https://doi.org/10.1111/1468-5957.00269

Harry, D., Linda, D., \& Rene, M. S. (2010). Seasoned equity offerings, market timing, and the corporate lifecycle. Journal of Financial Economics, 95, 275-295. https://doi.org/10.2139/ssrn.1000441

Hill, C. W. L., \& Snell, S. A. (1989). Effects of ownership structure and control on corporate productivity. Academy of Management Journal, 32, 25-46. https://doi.org/10.2307/256418

Hovakimian, A., Opler, T., \& Titman, S. (2001). The debt-equity choice. Journal of Financial and Quantitative Analysis, 36, 1-24.

Jenter D. (2005). Market timing and managerial portfolio decisions. Journal of Finance, 60, 1903-1949. https://doi.org/10.1111/j.1540-6261.2005.00783.x 
Kahle, K. M. (2000). Insider trading and the long-run performance of new security issues. Journal of Corporate Finance, 6, 25-53. https://doi.org/10.1016/S0929-1199(99)00015-2

Karpoff, J. M., \& Lee D. (1991). Insider trading before new issue announcements. Financial Management, 20, 18-26. https://doi.org/10.2307/3666093

Kothari, S. P., Shanken, J., \& Sloan, G. R. (1992). Another Look at the Cross-section of expected Stock Returns. Journal of Finance, 50, 185-224. https://doi.org/10.2307/2329243

Landsberger, H. A., Carlson, J. R., \& Campbell, R. T. (1998). Education policy in comparative perspective: Similarities in the underlying issues in debate among educational elites in Britain, the federal republic of Germany and the USA. Research Papers in Education, 3, 103-130. https://doi.org/10.1080/0267152880030203

Lee, I. (1997). Do firms knowingly sell overvalued equity? Journal of Finance, 52, 1439-1466. https://doi.org/10.2307/2329442

Lee, J. Z., \& Lin, T. H. (2001). The effect on wealth of outside stockholders resulting from adopting bookbuilding when seasoned equity offering. Journal of Contemporary Accounting, 2, 127-146. https://doi.org/10.6675/JCA.2001.2.2.01

Lin, H. N., \& Lu, C. L. (2004). The impacts of the ownership of institutional investor and insider on announcement effect of seasoned equity offerings. Working Paper, Kun Shan University.

Loughran, T., Ritter, J. R., \& Rydqvist, K. (1994). Initial public offerings: International insights. Pacific-Basin Finance Journal, 2, 165-199. https://doi.org/10.1016/0927-538X(94)90016-7

Louis, H., Sun, A. X., \& White, H. (2010). Insider trading after repurchase tender offer announcements: Timing $\begin{array}{llll}\text { versus informed } \text { trading. } & \text { Financial }\end{array}$ https://doi.org/10.1111/j.1755-053X.2010.01074.X

Lucas, D. J., \& Mcdonald, R. L. (1990). Equity issues and stock price dynamics. Journal of Finance, 45, 1019-1043. https://doi.org/10.2307/2328713

Seyhun, H. N. (1985). Insiders' profits, costs of trading, and market efficiency. Journal of Financial Economics, 16, 189-212. https://doi.org/10.1016/0304-405X(86)90060-7

Shiue, M. J., Lin, C. J., \& Liu, Y. P. (2009). Board Characteristics and overvalued equity: Evidence from Taiwan. International Research Journal of Finance and Economics, 32, 104-114.

Shu, P. G., \& Chiang, S. J. (2012). Why are seasoned equity overvalue? An alternative perspective from firm size, timing and earnings management. Working Paper, National Taiwan University.

Wang, H. L. (2005). Audit quality and earnings management by seasoned equity offering firms. Electronic Theses \& Dissertations Service, 1-58.

Wang, J., He, Y., \& Wei, K. C. J. (2014). A comprehensive study of liquidity before and after SEOs and SEO underpricing. Journal of Financial Markets, 20, 61-78. https://doi.org/10.1016/j.finmar.2014.03.004

\section{Notes}

Note 1. Nevertheless, Fu and Huang (2015) argue that the events after SOX are motivated more for business operating reasons than to exploit mispricing. Evgeniou, Junqué de Fortuny, Nassuphis, and Vermaelen (2017) confirm the findings of Fama and French (2015) that the SEO anomaly, i.e., SEO are followed by negative long-term excess returns, disappears after replacing the Fama and French (1993) three-factor model with the five-factor model.

Note 2. Amel-Zadeh et al. (2016) use SEC Form 4 footnote disclosures of insider sales to distinguish discretionary from nondiscretionary insider sales. They find that discretionary insider sales are informative to investors and result in significantly lower abnormal returns to the trade filing than nondiscretionary sales.

\section{Copyrights}

Copyright for this article is retained by the author(s), with first publication rights granted to the journal.

This is an open-access article distributed under the terms and conditions of the Creative Commons Attribution license (http://creativecommons.org/licenses/by/4.0/). 